Al-Azhar Bull. Sci. Vol. 18, No. 2 (Dec.): pp. 203-220, 2007.

\title{
SYNTHESIS AND PHYSICOCHEMICAL CHARACTERIZATION OF ZSM- 5 METALLOSILICATE ZEOLITES PREPARED BY ISOMORPHOUS SUBSTITUTION PROCESS
}

TAREK M. SALAMA

Faculty of Science, Chemistry Department, Al-Azhar University, Nasr City 11884, Cairo, Egypt. E-mail address: tm_salama@yahoo.com (T.M. Salama).

\begin{abstract}
Metal ions-containing ZSM-5 materials were prepared by isomrphous substitution of purely ZSM-5 using different metal ions, namely $\mathrm{Co}(\mathrm{II}), \mathrm{Ni}(\mathrm{II})$ and $\mathrm{Cu}(\mathrm{II})$. The metal modified ZSM-5 samples were synthesized hydrothermally in the presence of tetrapropyl ammonium bromide (TPABr) as the template and n-propyl amine $\left(\mathrm{n}-\mathrm{PrNH}_{2}\right)$ as the mobilizing agent. The structure, morphology, particle-size distribution, surface texture and acidity of these materials have been investigated and compared with ZSM-5 prepared by direct hydrothermal synthesis. The apparent effect of the substitution of $\mathrm{Al}$ by $\mathrm{Co}$ (II) ions on the crystal size results in a structural arrangement of the gel during aging-favoring nucleation. The surface area, degree of crystallinity and particle size of Co/ZSM-5 increase at the expense of pore radius, though $\mathrm{Ni}$ (II) and $\mathrm{Cu}$ (II) ions substituted ZSM-5 cause lesser effects. The M/ZSM-5 catalyst in the presence $\mathrm{H}_{2} \mathrm{O}_{2} / \mathrm{UV}$ is an active system for the oxidative color removal of Direct blue-1 in aqueous heterogeneous suspensions with a very low $\mathrm{M}(\mathrm{II}) / \mathrm{substrate}$ ratio. The high phase heterogeneity of Co/ZSM-5 catalyst account for the increased values of the activity than the corresponding $\mathrm{Ni} /$ and $\mathrm{Cu} / \mathrm{ZSM}-5$ ones.
\end{abstract}

Keywords: ZSM-5; Isomorphous substitution; In-situ FT-IR; Surface texture; particle-size distribution; XRD; Photocatalysis.

\section{Introduction}

The chemical composition, structure and extra framework cations of the zeolite significantly affect the adsorption-interaction of typical probe molecules with the zeolitic active sites, thus, strongly influencing the catalytic properties of the zeolitic material [1-3]. Different preparation methods have been reported in order to optimize the incorporation of metal ions in these processes. Methods range from solid and liquid-ion exchange [4-6], to chemical vapor deposition of volatile compound into the channels of zeolite [7-9]. In an early study by Tielen et al. $[10,11]$ the framework substitutions are nevertheless difficult to predict and generalize the theoretical possibilities and limitations of so called isomorphous substitutions. When a source of a redox metal ion is added to the synthesis gel of a zeolite this can result in isomorphous substitution of $\mathrm{Al}, \mathrm{Si}$ or $\mathrm{P}$ by the metal ion, 
whereby the latter occupies $\mathrm{TO}_{4}$ tetrahedra [12-14]. It has been acknowledged that the tetrahedral surrounding could be stable for cations with $0.414>\rho>0.225(\rho=$ $r_{M} / r_{O}$, where $r_{M}$ and $r_{O}$ are the radii of the cation and the oxygen ion, respectively). Other requirements for a true substitution imply some flexibility of the heteroatoms to accept the tetrahedral coordination with an oxidation state compatible with the overall framework charge $[15,16]$.

The incorporation of transition metal ions into the framework allow to prepare shape selective and redox molecular sieves. The framework substituted titanium(IV) silicalite (TS-1) provides the first example of the metallosilicate molecular sieve [17]. Some other elements that have, for example, the appropriate ionic size required for a stable tetrahedral coordination, are potential candidates for an extended incorporation. This is obviously the case of $\mathrm{Al}$ and $\mathrm{Ge}$ and, to a lesser extent, $\mathrm{Be}$, $\mathrm{Ga}, \mathrm{Fe}$ and $\mathrm{B}$.

Gabelica and Valange have discussed the potentialities and limitations of shortchain alkylamines as mobilizing-complexing agents for use as mineralizers for a variety of metallic ions in MFI zeolite syntheses [18]. More than two heteroatoms were found to be incorporated per MFI unit cell in the case of $\mathrm{Zn}, \mathrm{Al}, \mathrm{Ga}, \mathrm{Fe}, \mathrm{B}, \mathrm{Ge}$ and Ti. $\mathrm{Cd}^{2+}$ and $\mathrm{Cr}^{3+}$ ions only partly incorporate the MFI lattice $\left(\mathrm{M}^{\mathrm{n}+}\right.$ per unit cell <2). Nevertheless, copper, nickel, cobalt, manganese and molybdenum were found essentially admixed within the silicalite crystals. Besides the fact that these ions do not readily achieve a tetrahedral coordination, the other possible reason could be that their polycondensation, if any possible, does not occur when these species are involved in too strong complexes with methylamine.

Therefore, in this paper, it is a pre-requisite to incorporate coordinatively unsaturated extra-framework monometallic $\mathrm{M}^{2+}(\mathrm{M}=\mathrm{Ni}$ or $\mathrm{Cu}$ or $\mathrm{Co})$ into ZSM-5 of the MFI structure-type framework $[19,20]$. This was done by the hydrothermal isomorphous substitution of $\mathrm{Al}$ by $\mathrm{M}^{2+}$ which can be obtained from starting gel. The metallosilicate zeolites were characterized by XRD, FT-IR of pyridine adsorption and surface texture. The decolorization of Direct blue one (DB-1) in the presence of $\mathrm{H}_{2} \mathrm{O}_{2}$ and UV irradiation is also investigated with the aim of evaluating the metal ion effect on the process. DB-1 was chosen, as a model for the photocatalytic color removal experiment, because it is a nonvolatile common contaminant in the industrial wastewaters, thermally labile and a high-molecular weight compound. 


\section{Experimental}

\section{Materials}

The materials used were: silicic acid powder, sodium hydroxide pellets (A.R $98 \%$ ), aluminum sulfate $\left[\mathrm{Al}_{2}\left(\mathrm{SO}_{4}\right)_{3} .16 \mathrm{H}_{2} \mathrm{O}\right]$ (Merck), Tetrapropyl ammonium bromide and n-propyl amine (Merck), cobalt nitrate $\left[\mathrm{Co}\left(\mathrm{NO}_{3}\right)_{2} \cdot 6 \mathrm{H}_{2} \mathrm{O}\right]$ (Merck), cupper chloride $\left(\mathrm{CuCl}_{2}\right)$, Nickel Acetate $\left(\mathrm{Ni}\left(\mathrm{CH}_{3} \mathrm{COO}\right)_{2} .4 \mathrm{H}_{2} \mathrm{O}\right)$ and commercial $\mathrm{HCl}$ and $\mathrm{H}_{2} \mathrm{SO}_{4}$. Direct blue-1 dye [3,3'-Dioxo-1,3,1 $\square$ ',3'-tetrahydro-[2,2']-biindolylidene-5,5'-disulfonic acid disodium salt]<smiles>COc1cc(-c2ccc(N=Nc3ccc4c(S(N)(=O)=O)cc(S(=O)(=O)O)c(N)c4c3O)c(OC)c2)ccc1N=Nc1ccc(S(=O)(=O)O[Na])c(O)c1O</smiles>

M.F. $\mathrm{C}_{38} \mathrm{H}_{24} \mathrm{~N}_{6} \mathrm{Na}_{4} \mathrm{O}_{16} \mathrm{~S}_{4}$, M.Wt. 466.35 g/L. Maximum wavelength is $608 \mathrm{~nm}$; molar absorbtivity is $6309 \mathrm{~mol}^{-1} \mathrm{~cm}^{-1}$ and the dye content is $85 \%$ [Merck].

\section{Synthesis of ZSM-5}

Pure ZSM-5 was synthesized hydrothermally by using tetrapropyl ammonium bromide (TPABr) as the template and n-propyl amine $\left(\mathrm{n}-\mathrm{PrNH}_{2}\right)$ as the mobilizing agent. Silicic acid and aluminum sulfate were used as the $\mathrm{Si}$ and $\mathrm{Al}$ sources, respectively. The starting mixture was formed using the following molar composition:$$
\text { 3.12 } \mathrm{Na}_{2} \mathrm{O}: 0.162 \mathrm{Al}_{2} \mathrm{O}_{3}: 6.185 \mathrm{SiO}_{2}: 0.185 \mathrm{TPABr}: 100 \mathrm{H}_{2} \mathrm{O}
$$

For the procedure of synthesis, $\mathrm{Al}_{2}\left(\mathrm{SO}_{4}\right)_{3} \cdot 18 \mathrm{H}_{2} \mathrm{O}$ was first dissolved in distilled water, into which $0.05 \mathrm{ml}$ of concentrated $\mathrm{H}_{2} \mathrm{SO}_{4}$ was added, obtaining a solution named (A). The appropriate amounts of template, mobilizing agent, silicic acid, sodium hydroxide and distilled water were admixed, forming a solution named (B). This solution was added drop by drop to solution (A); after which the mixed solution was stirred for about $1 \mathrm{~h}$ to get a homogenous gel-mixture, which was transferred into a stainless-steel autoclave kept at $150{ }^{\circ} \mathrm{C}$ for 4 days under autogenous pressure. Thereafter, the solid product was filtered off, washed with distilled water until free of bromide, air-dried overnight at $120^{\circ} \mathrm{C}$, and finally calcined at $550^{\circ} \mathrm{C}$ for $6 \mathrm{~h}$.

\section{Preparation of M/ZSM-5}

The isomorphously substituted M/ZSM-5 solids were synthesized hydrothermally using TPABr and n-PrNH 2 . A solution of the silicic acid, TPABr, n$\mathrm{PrNH}_{2}$ and $\mathrm{NaOH}$ was added to a mixture of $\mathrm{Al}_{2}\left(\mathrm{SO}_{4}\right) 3 \cdot 18 \mathrm{H}_{2} \mathrm{O}$ and $\mathrm{M}$ (II) chloride 
$(\mathrm{M}=\mathrm{Co}, \mathrm{Ni}, \mathrm{Cu})$. The mixture was vigorously stirred at room temperature for $24 \mathrm{~h}$, then the amorphous gel formed was allowed to age for $1 \mathrm{~h}$ at the same temperature. Sulfuric acid $(0.1 \mathrm{M})$ or sodium hydroxide $(0.1 \mathrm{M})$ adjusted the $\mathrm{pH}$ to 11 . The molar composition of the gel was: $3.12 \mathrm{Na}_{2} \mathrm{O}: 0.138 \mathrm{Al}_{2} \mathrm{O}_{3}: 6.185 \mathrm{SiO}_{2}: 0.01375 \mathrm{M}: 0.185$ TPABr: $100 \mathrm{H}_{2} \mathrm{O}$, where $\mathrm{M}$ is expressed as $\mathrm{CoO}$ or $\mathrm{CuO}$ or $\mathrm{NiO}$.

The reaction mixture was transferred to $300 \mathrm{ml}$ stainless steel autoclaves and maintained in an oil bath at $160^{\circ} \mathrm{C}$ for 6 days under autogeneous pressure. At the end of crystallization, the autoclaves were removed from the oil bath after and quenched in cold water for products identification. The solid products were separated by filtration and washed thoroughly with distilled water until the $\mathrm{pH}$ of washing liquid was close to 8 . The products were then dried at $120^{\circ} \mathrm{C}$ for $10 \mathrm{~h}$. The as-synthesised samples (M/ZSM-5) in which $\mathrm{M}(\mathrm{II})$ is isothermally substituted in the zeolite framework, are calcined in air at $550{ }^{\circ} \mathrm{C}$ for $6 \mathrm{~h}$. These samples were referred to as Co/ZSM-5 or Ni/ZSM-5 or Cu/ZSM-5.

\section{Characterization techniques}

The X-ray diffractograms of various zeolitic samples were measured by using a Bruker axs, D8 advance. The patterns were run with Ni-filtered copper radiation $(\lambda$ $=1.5404 \AA$ ) at $30 \mathrm{kV}$ and $10 \mathrm{~mA}$ with a scanning speed of $2 \theta=2.5^{\circ} \mathrm{min}^{-1}$. For phase identification purposes, automatic JCPDS library search and match were used.

The crystal sizes of the prepared materials were determined using the Scherrer equation. The instrumental line broadening was measured using a LaB6 standard. The crystallinity of the prepared samples was calculated using the ratio of the sum of the areas of the most three intense peaks for the prepared samples at $2 \theta=23-24^{\circ}$ multiplying by 100 .

The FT-IR spectra were recorded at room temperature using Jasco FT-IR-40 apparatus in the range $1300-450 \mathrm{~cm}^{-1}$ with a resolution of $2 \mathrm{~cm}^{-1}$ using the $\mathrm{KBr}$ pellet technique. The in situ FT-IR spectra of pyridine adsorption were recorded using the same spectrometer. The sample was pressed into self-supporting wafer using $20 \mathrm{mg} / \mathrm{cm}^{2}$ before being mounted between $\mathrm{CaF}_{2}$ windows attached to a quartz infrared cell. This cell was equipped with an electric furnace for heat treatment. Prior each experiment was initiated the sample was degassed at $300^{\circ} \mathrm{C}$ before 5 Torr of pyridine was admitted to the IR cell at room temperature.

The particle size distribution analysis of various zeolitic samples was measured using a particle size analyzer (LB-500 HORIBA, Dynamic Light Scattering). The sample was stirred with $10 \mathrm{ml}$ of sodium hexametaphosphate in $90 \mathrm{ml}$ of distilled 
water for $10 \mathrm{~min}$. The resulting dispersion was placed in an ultrasonic bath for 10 $\min .3 \mathrm{ml}$ of the suspension was placed in a cell for measurement.

The Nitrogen adsorption isotherms were measured at $-196^{\circ} \mathrm{C}$ using a conventional volumetric apparatus. The specific surface area was obtained using the BET method. The micropore volume and pore radius were determined from the $\mathrm{t}$ plot method.

\section{Catalytic activity}

Decolorization experiments of DB-1 on the various preparations in the presence of $\mathrm{H}_{2} \mathrm{O}_{2} / \mathrm{UV}$ ultraviolet irradiation were carried out in a batch mode. A $100 \mathrm{ml}$ volume of the DB-1 dye (100 ppm), previously adjusted to a fixed $\mathrm{pH}$ value with diluted $\mathrm{NaOH}$ and $\mathrm{HCl}$ solutions, was added to a $250 \mathrm{ml}$ beaker containing different amounts of suspended catalysts. The suspension was immediately shaken in an air for 30 min using a magnetic stirrer prior to following up the uptake amount of the dye. All the experiments were carried out using a horizontal cylinder annular batch reactor. A black light-blue florescent bulb (F18W- BLB) was positioned at the axis of the reactor to supply UV illumination. The light intensity after passing through a reaction suspension was $365 \mathrm{~nm}$. The reaction was carried out isothermally at $25^{\circ} \mathrm{C}$ and samples of the reaction mixture were taken at time intervals for a total reaction time $1 \mathrm{~h}$. The disappearance of DB-1 was analyzed by (JASCO V-570 unit, serial No 29635) over the range $190-800 \mathrm{~nm}$. Calibration plots based on Beer-Lamberts law were established relating the absorbance to the concentration. The decolorization was determined at $\lambda$ maximum $=614 \mathrm{~nm}$. The percent removal efficiency of DB-1 was calculated by applying the following equation:

$$
\% \text { Removal efficiency }=(\mathrm{Co}-\mathrm{C}) / \mathrm{Co} \times 100
$$

where $\mathrm{Co}$ and $\mathrm{C}$ are the concentrations of original DB-1 and after a reaction time of $1 \mathrm{~h}$, respectively.

\section{Results and Discussion}

\section{$X R D$ and particle size distribution}

Inspection of the X-ray diffractograms characterizes the metallosilicate samples to be similar to pure ZSM-5 (Fig. 1), which is found to be in good arrangement with the MFI framework topology when compared to a standard pattern of ZSM-5 [21]. Least square analysis of the data gave the values for unit-cell parameters for synthesized ZSM-5 closely allied to those for the standard. This indicates that complete crystallization had occurred without any impurity. It is worth noting that ZSM-5 preserves its crystallinity even under hydrothermal isomorphous substitution 
of $\mathrm{Al}$ by $\mathrm{M}^{2+}$ especially for Co/ZSM-5. In $\mathrm{M}^{2+}$ modified-ZSM-5, due to the presence of metal ions is believed to undergo some molecular distortion and this could potentially provide a way to effectively stabilize metal ions in channel intersections of ZSM-5. However, the minor deviations in lattice cell parameters may reveal this prospect (Table 1).

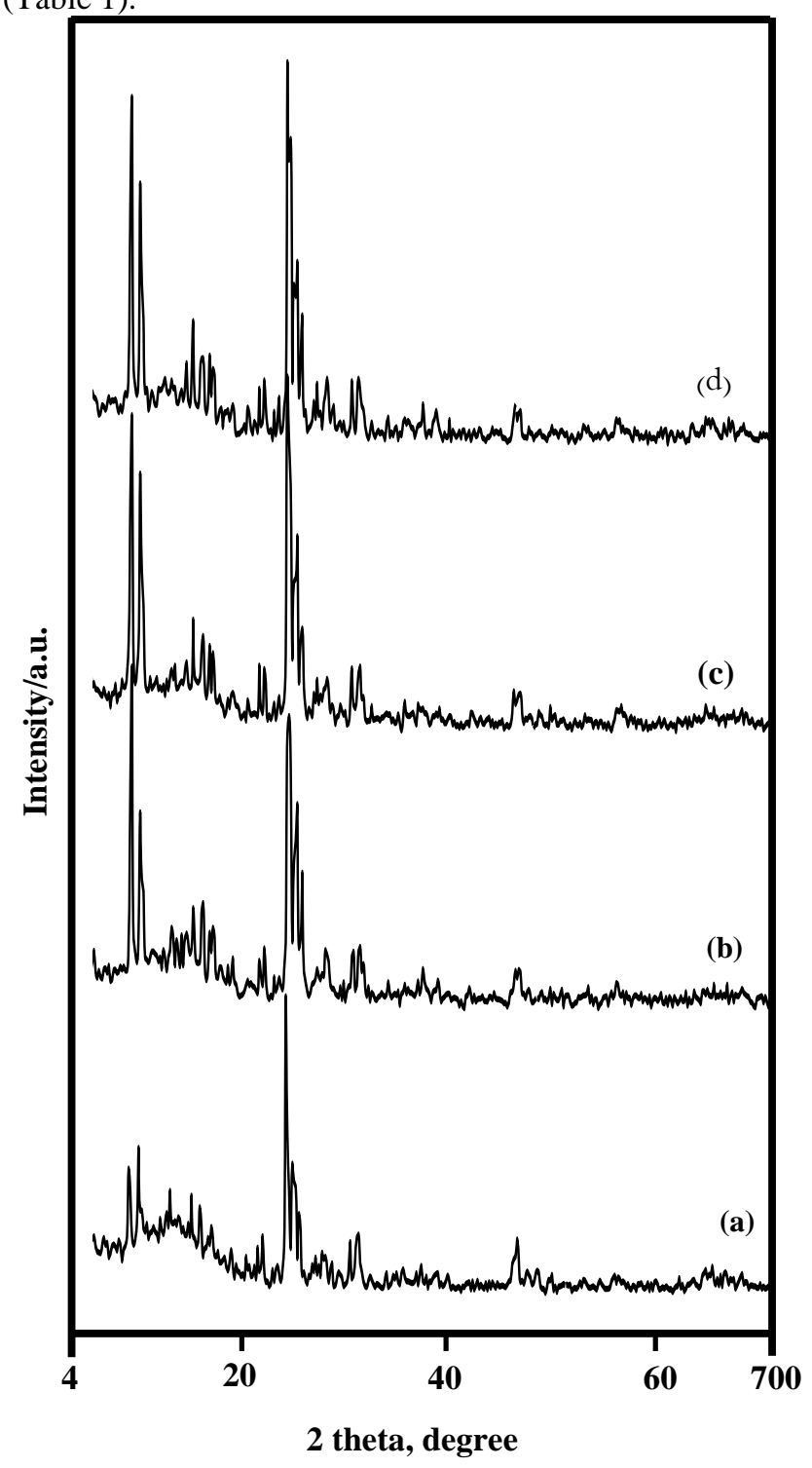

Fig. 1. X-ray diffractograms of
(a) ZSM-5,
(b) Ni/ZSM-5,
(c) $\mathrm{Cu} / \mathrm{ZSM}-5$ and
(d) Co/ZSM-5. 


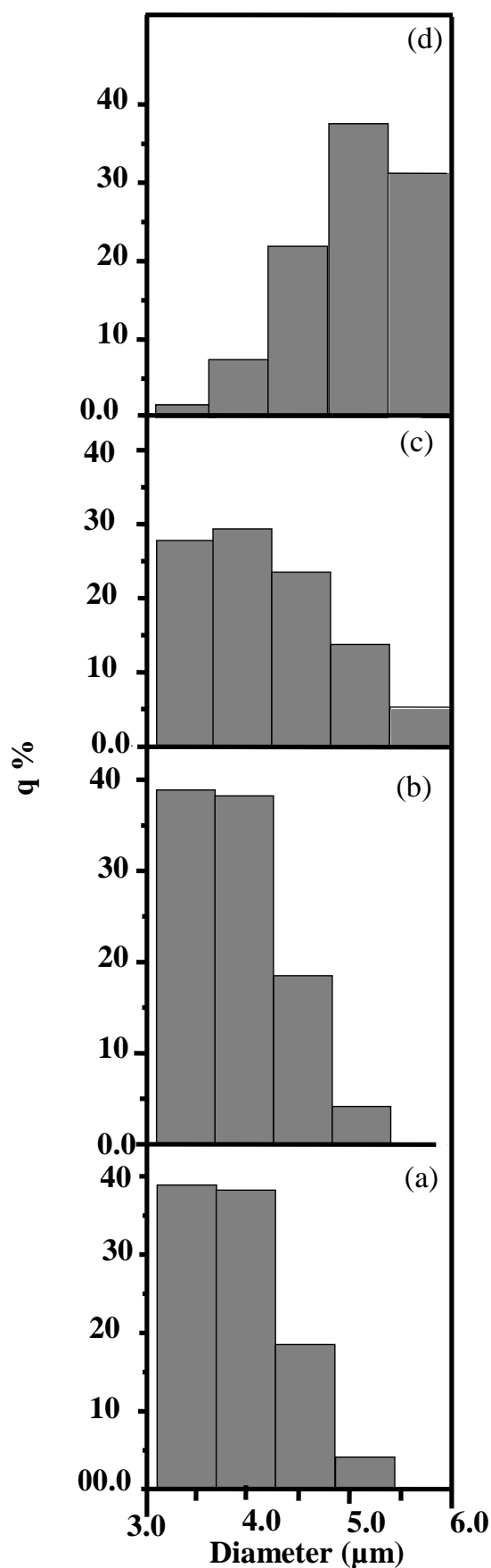

Fig. 2. The distributions of the particle size of the preparations prepared by the hydrothermal treatment for (a) ZSM-5, (b) Ni/ZSM-5, (c) Cu/ZSM-5 and (d) Co/ZSM-5 
Table 1. Unit cell parameters and crystallinity of the different preparations

\begin{tabular}{|c|c|c|c|c|c|c|c|}
\hline \multirow{2}{*}{ Samples } & \multirow{2}{*}{$\begin{array}{c}\text { Crystal } \\
\text { size (nm) }\end{array}$} & \multicolumn{3}{|c|}{ Lattice parameter $(\AA)$} & \multirow{2}{*}{$\begin{array}{c}\text { Cell } \\
\text { volume } \\
(\AA \dot{A})^{3}\end{array}$} & \multirow{2}{*}{$\begin{array}{c}\text { Crystallinity\% } \\
\text { estimated from } \\
\text { XRD } \\
\end{array}$} & \multirow{2}{*}{$\begin{array}{c}\text { Crystallinity\% } \\
\text { estimated from } \\
\text { IR } \\
\end{array}$} \\
\hline & & $\mathrm{a}$ & $\mathrm{b}$ & $\mathrm{c}$ & & & \\
\hline ZSM-5 & 108.28 & 20.205 & 20.046 & 13.429 & 5438.872 & 58 & 54 \\
\hline Ni/ZSM-5 & 187.40 & 20.039 & 19.467 & 13.354 & 5209.331 & 77 & 65 \\
\hline $\mathrm{Cu} / \mathrm{ZSM}-5$ & 135.46 & 19.816 & 20.126 & 13.636 & 5437.951 & 93 & 86 \\
\hline Co/ZSM-5 & 465.32 & 20.042 & 20.189 & 13.385 & 5415.966 & 100 & 94 \\
\hline
\end{tabular}

The particle sizes distribution of the agglomerated synthesized samples determined by particle size analysis are shown in Fig. 2 . The averages of the particle size for pure ZSM-5 and Ni/ZSM-5 are similar to each other, e. g. $4 \mu \mathrm{m}$. Apparently, this results from the absence of isomorphous substitution of $\mathrm{Al}$ by $\mathrm{Ni}^{2+}$ in $\mathrm{Ni} / \mathrm{ZSM}$ 5. A broad sizes distribution for Cu/ZSM-5 with an average particle size of $4 \mu \mathrm{m}$ can be shown in Fig. 2. The width of the particle size distribution can be determined by calculating the size span of crystals. Although the average size did not greatly change between $\mathrm{Ni} /$ and $\mathrm{Cu} / \mathrm{ZSM}-5$, particles with a size larger than $5 \mu \mathrm{m}$ were formed in Cu/ZSM-5. The Co/ZSM-5 particle size distribution presented in Fig. 2 shows that the distribution in this sample is broader and shifted to larger sizes than in the other samples. The average size is $\approx 5.2 \mu \mathrm{m}$ suggesting that the larger ionic radii of $\mathrm{Co}^{2+}\left(\mathrm{R}_{i} / \AA=0.56, C N=4\right)$ may influence the particle growth by replacing $\mathrm{Al}^{3+}\left(\mathrm{R}_{i} / \AA=0.39, C N=4\right)$ in the unit cell void. These data were confirmed by the values of crystal size evaluated from XRD (Table 1).

IR spectra

In Fig. 3a-d, FT-IR spectra of the transition metal modified ZSM-5, along with as-synthesized ZSM-5. The IR spectrum of ZSM-5 shows bands at 1228, 1060, 802, 549 and $478 \mathrm{~cm}^{-1}$, which are assigned to different vibrations of tetrahedral and framework atoms in ZSM-5 zeolite [22]. The bands at about 1000, and $465 \mathrm{~cm}^{-1}$ are due to internal vibrations of $(\mathrm{Si}, \mathrm{Al}) \mathrm{O}_{4}$ tetrahedra of $\mathrm{ZSM}-5$, whereas the bands at about 1100,800 , and $550 \mathrm{~cm}^{-1}$ are due to vibrations related to external linkages between tetrahedra and hence sensitive to framework structure. The IR spectra of M/ZSM-5 bring about significant changes in the structural region of zeolite pore. The Band near $1224 \mathrm{~cm}^{-1}$ which signifies the formation of crystalline ZSM-5 is nearly nonexistent in the spectrum of pure ZSM-5 (Fig. 3a). Therefore, only partial formation of ZSM-5 zeolite crystals exists at this point. The IR spectra of solids obtained after introduced metal ions include not only the $1224 \mathrm{~cm}^{-1}$ band specifying the existence of pores with 3D channels, but also growing bands at 546 and $798 \mathrm{~cm}^{-1}$ indicating the complete crystalline structure of M/ZSM-5 samples. These effects were maximized for Co/ZSM-5, in compatible with XRD and particle size distribution data. 


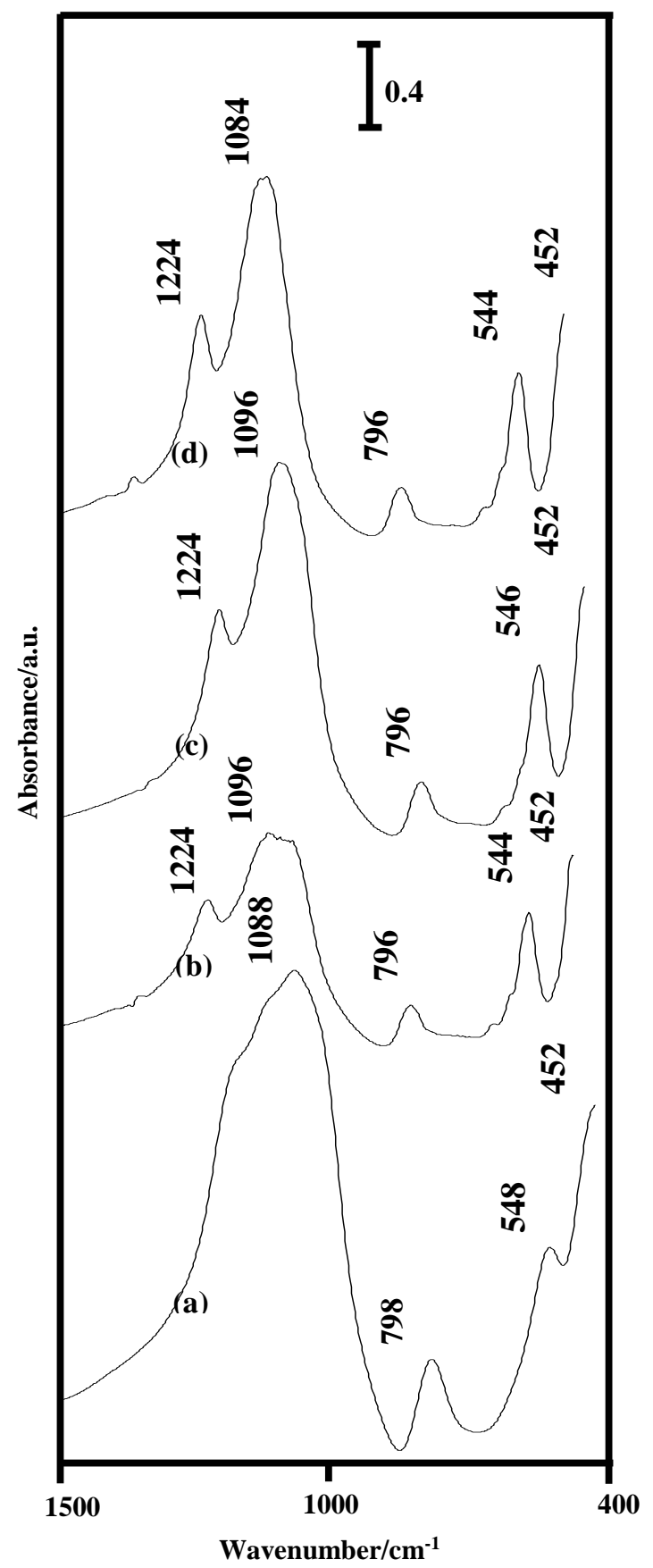

Fig. 3. FT-IR spectra of (a) ZSM-5, (b) Ni/ZSM-5, (c) Cu/ZSM-5 and (d) Co/ZSM-5. 
The IR absorption band at $450 \mathrm{~cm}^{-1}\left(\mathrm{I}_{450}\right)$ can be taken as indicative of the vibration of $\mathrm{TO}_{4}$ units, and that at $550 \mathrm{~cm}^{-1}\left(\mathrm{I}_{550}\right)$ is attributable to the vibration of 5 membered oxygen rings [23-25]. The relative intensity ratio $\mathrm{I}_{550} / \mathrm{I}_{450}$ (the ratio of the IR adsorption band at $550 \mathrm{~cm}^{-1}$ to that $450 \mathrm{~cm}^{-1}$ ) expresses a quantitative index of crystallinity around the oxygen rings of ZSM-5. As can be seen in Table 1, the results show that the ratio and consequently relative crystallinity increased in the following order: CoZSM-5 > CuZSM-5 > NiZSM-5 > ZSM-5 that is in close agreement with that calculated from XRD.

\section{Pyridine adsorption}

Fig. 4 displays the in situ infrared spectra of adsorbed pyridine as the probe molecule on M/ZSM-5 solids, as well as on ZSM-5. The spectrum of Py/ZSM-5 at $100^{\circ} \mathrm{C}$ displays bands at 1444 and $1597 \mathrm{~cm}^{-1}$ characteristic of Lewis-coordinated pyridine [Lpy] whereas the bands at 1544 and $1633 \mathrm{~cm}^{-1}$ are due to Brønstedcoordinated pyridine (Bpy).

The assignment of these bands was in agreement with those given by Parry [26]. The band at $1490 \mathrm{~cm}^{-1}$ is due to Lewis and Brønsted-coordinated pyridine (Lpy + Bpy). The high temperature evacuation $\left(150\right.$ and $\left.200^{\circ} \mathrm{C}\right)$ did not change the nature of acid sites but indeed caused a decrease in intensity of some bands.

On Ni/ZSM-5, Cu/ZSM-5 and Co/ZSM-5, Py adsorption at $100^{\circ} \mathrm{C}$ showed an enhancement in both Lewis and Brønsted acidity when compared to those of parent sample. The observation of increasing Lewis acidity can be explained by a surface model in which the tetrahedrally coordinated metal species did not occupy $\mathrm{Al}^{3+}$ coordinatively unsaturated site (cus), but rather created their individual $\mathrm{M}^{2+}$ cus [27]. The improvement in Brønsted acidity is likely attributed to the presence of a well dispersed metal ion in tetrahedral configuration. The $\mathrm{M}^{2+}$ ions attached hydroxyl groups would extend in the channels of ZSM-5 and allow more effective coordination to pyridine ligand. This result was manifested by the development of a band at the higher frequency side $\left(1657 \mathrm{~cm}^{-1}\right)$ assigned to pyridine attached to a stronger Brønsted site. However, this band did not develop in the spectrum of ZSM5. Finally, in the study [28], it was concluded that the decrease of the extent of dealumination results in an increase of the strength of the Brønsted sites. Evidently, the stepwise heating of the M/ZSM-5 samples provide the largest desorption peaks strength of acid sites, in contrast to the individual desorption peaks for pure ZSM-5. This must provide a further evidence of the facile procedure for the synthesis of M/ZSM- 5 by substitution of $\mathrm{Al}$ by $\mathrm{M}^{2+}$ metal species in the zeolite matrix has been found. 

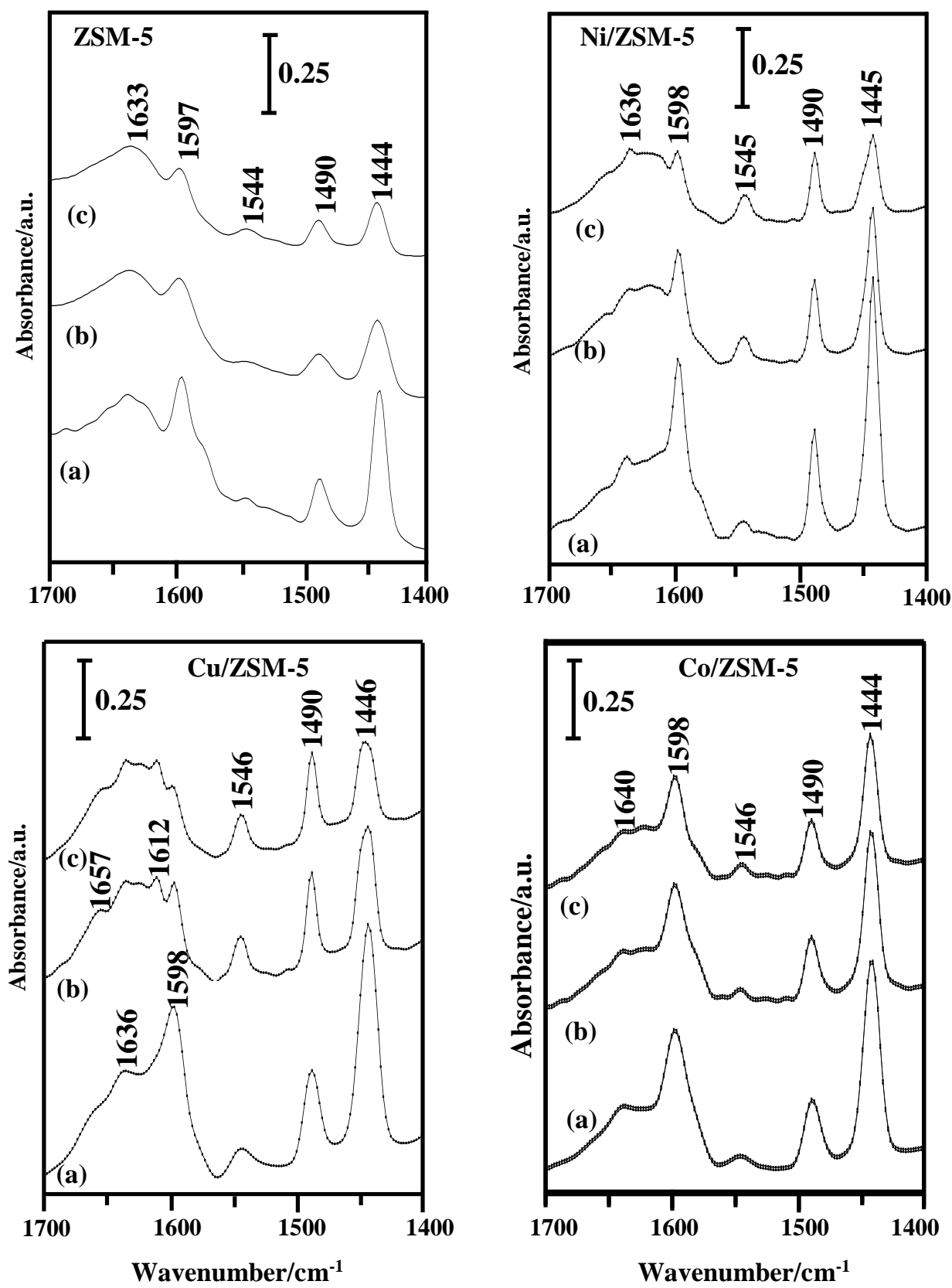

Fig. 4. In situ FT-IR spectra of pyridine adsorbed on the different samples after evacuation at $1 \times 10^{-4}$ Torr at (a) $100^{\circ} \mathrm{C}$, (b) $150^{\circ} \mathrm{C}$ and (d) $200^{\circ} \mathrm{C}$. 


\section{Surface texture}

The textural properties of the various samples were investigated by nitrogen adsorption at liquid nitrogen temperature and the calculated data are presented in Table 2. As a general trend, the isotherms all exhibit type I adsorption according to Brunauer classification as expected for microporous solids (not shown). The data in Table 2 reveal principally the following: (i) the obtained significant increase in BET surface areas and pore volumes of the M/ZSM-5 samples compared to those of pure ZSM-5 confirm the high crystallinity documented by the XRD and IR

Table 2. Some texture characteristics of the different preparations

\begin{tabular}{cccccccccccc}
\hline Sample & $\begin{array}{c}\mathrm{S}_{\mathrm{BET}} \\
\left(\mathrm{m}^{2} / \mathrm{g}\right)\end{array}$ & $\begin{array}{c}\mathrm{S}_{\mathrm{t}} \\
\left(\mathrm{m}^{2} / \mathrm{g}\right)\end{array}$ & $\begin{array}{c}\mathrm{S}^{\mu} \\
\left(\mathrm{m}^{2} / \mathrm{g}\right)\end{array}$ & $\begin{array}{c}\mathrm{S}^{\text {ext }} \\
\left(\mathrm{m}^{2} / \mathrm{g}\right)\end{array}$ & $\begin{array}{c}\mathrm{S}^{\text {wid }} \\
\left(\mathrm{m}^{2} / \mathrm{g}\right)\end{array}$ & $\begin{array}{c}\mathbf{r}^{-} \\
(\AA)\end{array}$ & $\begin{array}{c}\mathrm{Vp}^{\text {total }} \\
\left(\mathrm{cm}^{3} / \mathrm{g}\right)\end{array}$ & $\begin{array}{c}\mathrm{V}_{\mathrm{p}}^{\mu} \\
\left(\mathrm{cm}^{3} / \mathrm{g}\right)\end{array}$ & $\begin{array}{c}\mathbf{V}_{\mathrm{p}}^{\text {wid }} \\
\left(\mathrm{cm}^{3} / \mathrm{g}\right)\end{array}$ & $\begin{array}{c}\mathrm{C}- \\
\text { const. }\end{array}$ & $\begin{array}{c}\text { Microporosity } \\
\%\end{array}$ \\
\hline ZSM-5 & 429 & 420 & 422 & 74 & 7 & 24 & 0.4166 & 0.4054 & 0.0112 & 21 & 97 \\
Ni/ZSM-5 & 614 & 610 & 497 & 199 & 117 & 20.53 & 0.5042 & 0.4084 & 0.0958 & 139 & 81 \\
Cu/ZSM-5 & 692 & 685 & 651 & 260 & 41 & 20.67 & 0.5721 & 0.5384 & 0.0337 & 70 & 94 \\
Co/ZSM-5 & 675 & 655 & 602 & 241 & 73 & 15.81 & 0.4267 & 0.3806 & 0.0462 & 102 & 89 \\
\hline
\end{tabular}

Note: $\mathrm{S}_{\mathrm{BET}}$ : total surface area by using BET method; $\mathrm{S}_{\mathrm{t}}$ : specific surface area determined from $\mathrm{V}_{1-\mathrm{t}}$ plots of different adsorbents; $\mathrm{S}^{\mu}$ : surface area of microspores; $\mathrm{S}^{\text {ext }}$ : external surface area of micropores; $\mathrm{S}^{\text {wid: }}$ surface area of wide pores ; r: average pore radius; $\mathrm{V}^{\text {total }}$ : total pore volume at $\mathrm{p} / \mathrm{p}^{\circ}=0.95$; $\mathrm{Vp}^{\mu}$ : volume of micropores; $\mathrm{Vp}^{\text {wid. }}$ : volume of wide pores.

analysis. This points to the creation of larger pores occurring concomitant with replacing of $\mathrm{Al}$ from lattice position by $\mathrm{M}^{2+}$. This can be taken as an indication that pore filling by $\mathrm{M}^{2+}$ cations is essentially not accomplished by the hydrothermal substitution procedures used in this study. (ii) The average pore radii of M/ZSM5 are displaced toward ever decreasing values compared to that of pure ZSM-5. These results show that M/ZSM-5 had narrower pore entrances, probability due to $\mathrm{M}^{2+}$ cations located in $\mathrm{Al}$ compensation positions (tetrahedral sites), than the corresponding ZSM-5. If this is the case, the actual pore radius would determine a lower diffusion coefficient. The Co/ZSM-5 sample measured the lowest pore radius

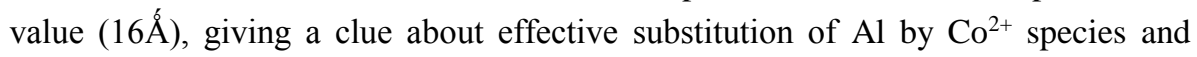
thus, indicates a lower value of $\mathrm{V}_{\mathrm{p}}{ }^{\text {total }}$ when compared with those of Ni/ZSM-5 or Cu/ZSM-5 samples. 


\section{Catalytic activity}

To obtain relevant information about the removal efficiency of DB-1 color, it was necessary to carry out experiments from which any possible direct photolysis was excluded. Experiments were made (i) in the absence of preparations (neat photochemical regime) and (ii) in the presence of $\mathrm{H}_{2} \mathrm{O}_{2}$ under $\mathrm{UV}$-illuminated $\mathrm{SiO}_{2}$ and $\mathrm{Al}_{2} \mathrm{O}_{3}$ to detect any possible contact mass effect. In both cases, no disappearance of DB-1 was observed. Increasing the percent decolorization efficiency of DB-1 on Co/ZSM-5 compared with the other synthesized samples is accounted for effective oxidative degradation of the dye interestingly in the UV irradiation (Fig. 5). The electronic absorption spectra recorded for this reaction (Fig. 6) clearly show that, the absorption band at $614 \mathrm{~nm}$ decreases with the progress of the reaction. This peak accounts for the blue color of solutions and can be attributed to the $n \rightarrow \pi$ (transition of the non-bonding electrons to the anti-banding $\pi$ ) group orbital of the double bond system and it is used to monitor the decolorization of the dye. In the UV region,

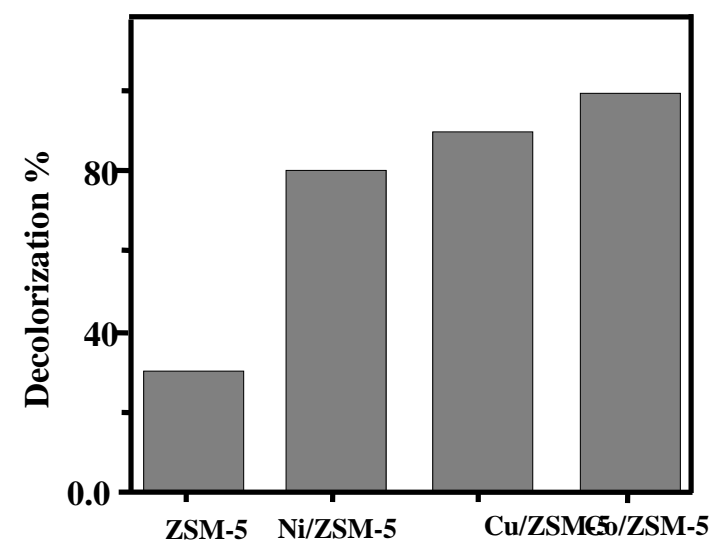

Fig. 5. The decolorization percentages of DB-1 over the different preparations at experimental conditions: $\mathrm{pH}=8$, reaction volume $=100 \mathrm{ml}$, catalyst amount $=$ $100 \mathrm{mg}, \mathrm{H}_{2} \mathrm{O}_{2}$ concentration $=0.3 \mathrm{M}$, initial dye concentration $=100 \mathrm{ppm}$, reaction time $=60 \mathrm{~min}$

there is a second group of bonds, with an increasing absorbency towards lower wavelengths, characteristic of aromatic rings. It was observed that the position of the maximum absorption wavelengths varied, depending on the solution concentration. In addition, no new absorption peaks occurred near the original maximum (Fig. 6). The calculated amount of $\mathrm{CO}_{2}$ evolved from the reaction that was captured by an aqueous solution of barium hydroxide and determined gravimetrically as precipitated barium carbonate measured $65 \%$ of the dye carbon atoms calculated 
theoretically. The sulphate ions, on the other hand, determined as barium sulphate using barium chloride solution measured a lower value than that expected from stoichiometry probably due to the adsorption of some sulphate ions on the catalyst surface. These results indicate that oxidative degradation of DB-1 on M/ZSM-5 can be proposed. The process may comprise the diffusion of the dye to the particle surface to form a complex, followed by exchange of electrons with the active sites on the surface in the presence of $\mathrm{Co} / \mathrm{ZSM}-5 / \mathrm{H}_{2} \mathrm{O}_{2} / \mathrm{UV}$ scheme. For DB-1 as a hydrophilic substrate, it may easily diffuse to and accumulate at the surface active sites of the catalyst facilitated by the decreased $\mathrm{pH}$ of the reaction mixture that was constant at 8 . Thus, one can postulate that the electrostatic attraction between the protonated dye molecules and $\mathrm{CoO}$ moieties can takes place in this $\mathrm{pH}$ range [29]. Given that the solution acquired almost an acidic nature, an increase in the oxidation ability can be expected specifically because the point of zero charge of $\mathrm{CoO}$ is around $\mathrm{pH}$ 8. In conclusion, an optimum in activity as a function of the particle size as increased phase heterogeneity of $\mathrm{CoO}$ particles stabilized in the ZSM-5 matrix would have special catalytic properties.

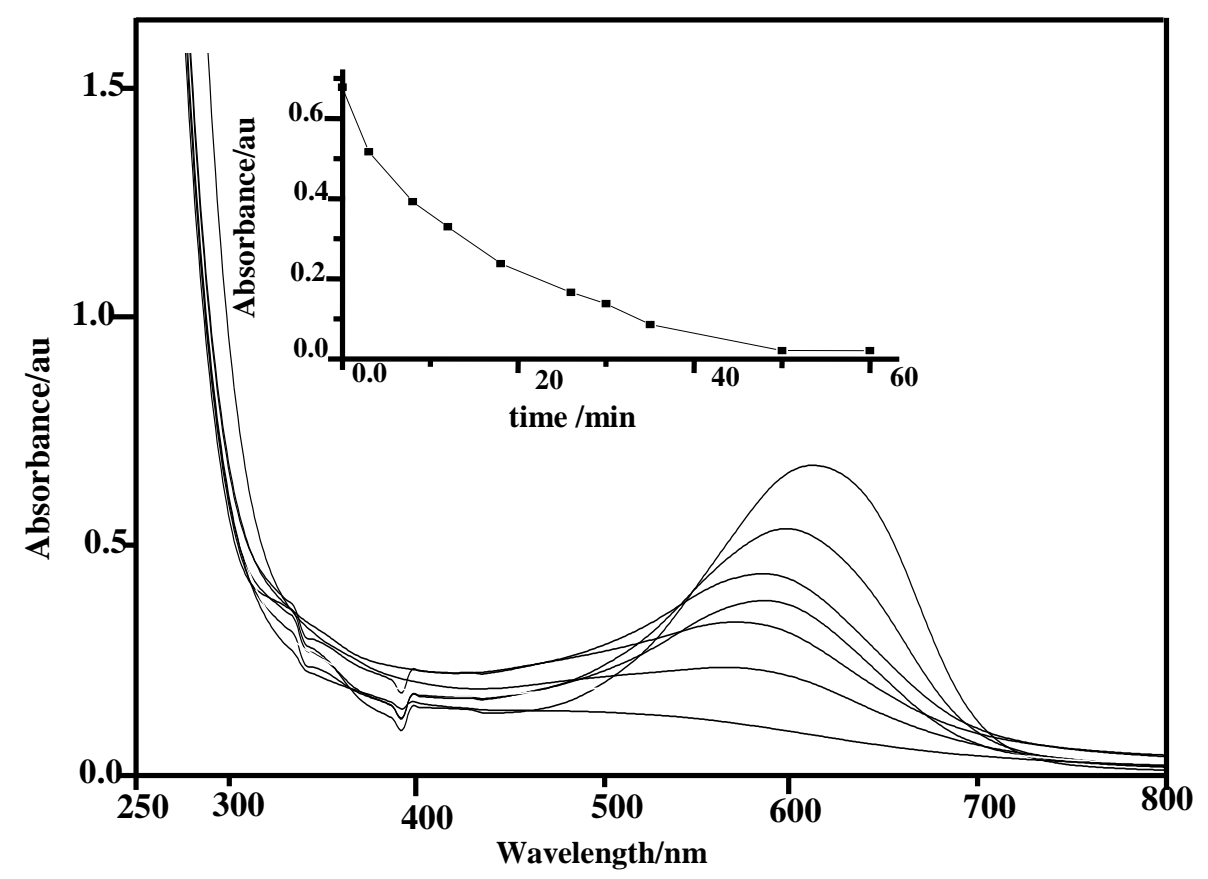

Fig. 6. Time resolved absorption spectra of the reaction of DB-1 on Co/ZSM-5 at experimental conditions: $\mathrm{pH}=8$, reaction volume $100 \mathrm{ml}$, catalyst amount $=$ $100 \mathrm{mg}, \mathrm{H}_{2} \mathrm{O}_{2}$ concentration $=0.3 \mathrm{M}$, initial dye concentration $=100 \mathrm{ppm}$. 
pH effect

The decolorization efficiency of DB-1 on Co/ZSM-5 in ultraviolet irradiation at different $\mathrm{pH}$ levels is shown in Fig. 7. The solutions of DB-1 are adjusted to the desired $\mathrm{pH}$ by addition of aqueous solutions of $\mathrm{HCl}$ or $\mathrm{NaOH}$. The different concentrations of acid or base have been chosen in order to add the minimum quantity of these species to avoid the volume change of the reaction mixture. It was found that the decolorization of DB-1 over Co/ZSM-5 was highly $\mathrm{pH}$ dependent, with the decolorization efficiencies increased with decreasing $\mathrm{pH}$ values. At $4>\mathrm{pH}$ $>9$, the decolorization of the DB-1 was negligible. The maximum decolorization occurred near $\mathrm{pH} \mathrm{8}$, at the point of zero charge (PZC) of $\mathrm{CoO}$ [29]. Hence, the oxidizing ability of $\mathrm{CoO}$ can be sharply enhanced since the dye has negatively charged sulfonic groups in its structure, in which the acidic solution favors its adsorption onto catalyst surface.

Fig. 7

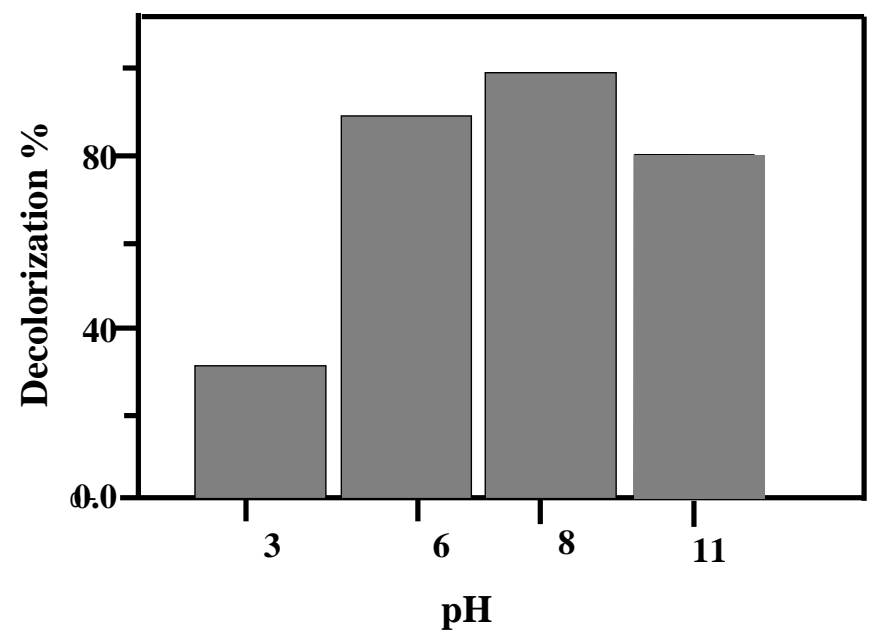

Fig. 7. Effect of pH values on the decolorization efficiency of DB-1 on Co/ZSM-5.

IR spectra of recycled Co/ZSM-5

The residual activity of Co/ZSM-5 was determined by following the reaction in the adsorbed phase after the addition of successive portions of reactant. The FT-IR spectra of the recycled sample were monitored at reaction conditions of $\mathrm{pH} 8$ and 11, in comparison with the fresh sample. As it can be seen, the spectrum of Co/ZSM-5 is characterized by as oxidized adsorbed fragment of carboxylate - $\mathrm{COO}$ groups that 
can be identified by the absorption band at $1492 \mathrm{~cm}^{-1}\left(v_{\mathrm{s}}\right)$. The $v_{\mathrm{as}}$ vibration of the same species is obscured by the bending mode of adsorbed water molecules at $1635 \mathrm{~cm}^{-1}$. Besides, the development of a doublet around $2335 \mathrm{~cm}^{-1}$ due to adsorbed $\mathrm{CO}_{2}$ species, along with the presence of organic species at 1984 and $1868 \mathrm{~cm}^{-1}$, confirm the photocatalytic degradation of DB-1 on the recycled Co/ZSM-5. It is also obvious that this catalyst is more active for this reaction at $\mathrm{pH} 8$.

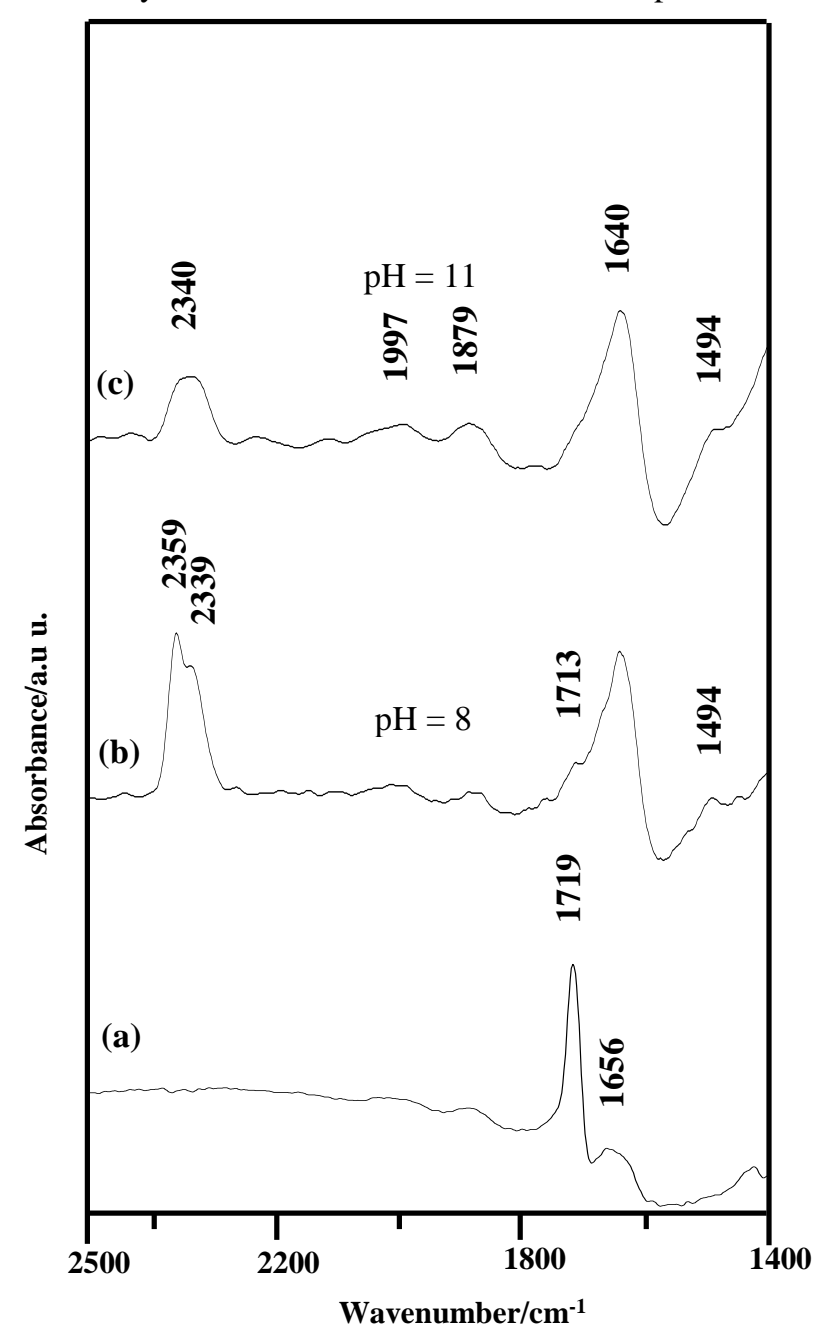

Fig. 8. FT-IR spectra of photocatalytic degradation of DB-1 on (a) fresh Co/ZSM-5; (b and c) recycled Co/ZSM-5 at reaction conditions of pH 8 and 11, respectively. 


\section{Conclusions}

Successful attempts have been made to prepare large particles of isomorphously substituted $\mathrm{Al}$ in framework of ZSM-5 by heteroatoms $\mathrm{Co}, \mathrm{Ni}$ and $\mathrm{Cu}$ in tetrahedral sites. The four-fold increase in the metal ions modified silica module of ZSM-5 provides significant changes in the samples acidity. It could be proved the significant increase in the particle sizes as a result of the structural peculiarities of the lattice due to the isomorphous substitution of heteroatoms in the later. Changes in the topology due to the variations of the lattice structure, could increase the phase heterogeneity as the broad particle size distribution of the modified ZSM5. The influence of these factors in catalytic activity can be particularly sharp. In this case photocatalytic degradation of DB-1 in the presence of $\mathrm{H}_{2} \mathrm{O}_{2} / \mathrm{UV}$ irradiation appears to be activated on these materials.

\section{References}

1. S. T. Wilson, B.M. Lock, E.M. Flanigen, US Patent 4,310, 440 (1982).

2. D. B. Akolekar, J. Catal. 144 (1993) 148.

3. E. M. Flanigen, R.L. Patton, S.T. Wilson, Stud. Surf. Sci. Catal. 37 (1988)13.

4. R.Q. Long, R.T. Yang, Chem. Commun. (2000) 1651.

5. R. Joyner, M. Stockenhuber, J. Phys. Chem. B 103 (1999) 5963.

6. M. Kögel, R. Mönnig, W. Schwieger, A. Tissler, T. Turek, J. Catal. 182 (1999) 470.

7. H-Y. Chen, W.M.H. Sachtler, Catal. Today 42 (1998) 73.

8. G. Centi, F. Vazanna, Catal. Today 53 (1999) 683.

9. P. Marturano, L. Drozdova', A. Kogelbauer, R. Prins, J. Catal. 192 (2000) 236.

10. M. Tielen, M. Geelen, P.A. Jacobs, Acta Phys. Chem. 31 (1985) 1.

11. J. A. Martens, M. Tielen and P.A. Jacobs, Stud. Surf. Sci. Catal., 46 (1985) 49.

12. C. Kladis, S.K. Bhargava, K. Foger, D.B. Akolekar, J. Mol. Catal. A: Chem. 175 (2001) 241.

13. Z. Gabelica, S. Valange, Micropor. Mesopor. Mater. 30 (1999) 57.

14. G. Centi, S. Perathoner, Appl. Catal. A: 132 (1995) 179.

15. T. M. Salama, M. M. Mohamed, I. Othman, G.A. El-Shobaky, Appl. Catal. A: 86 (2005) 85.

16. M. M. Mohamed, T. M. Salama, I. Othman, G.A. El-Shobaky, Appl. Catal. A: 286 (2005) 85. 
17. M. Crocker, R. H.M. Herold, B. G. Roosenbrand, K. A. Emeis, E. Wilson, Coll. Surf. A: Physicochem. Eng. Asp. 139 (1998) 351.

18. Z. Gabelica, S. Valange, Micropor. Mesopor. Mater. 30 (1999) 57.

19. C. Lamberti, S. Bordiga, M. Salvalaggio, G. Spoto, A. Zecchina, F. Geobaldo, G. Vlaic, M. Bellatreccia, J. Phys. Chem. B 101 (1997) 344.

20. A. Zecchina, S. Bordiga, M. Salvalaggio, G. Spoto, D. Scarano, C. Lamberti, J. Catal. 173 (1998) 500.

21. A.N. Kotasthane, V.P. Shiralkar, S.G. Hegde, S.B. Kulkarni, Zeolites 6 (1986) 253.

22. P.A. Jacobs, H.K. Beyer, J. Valyon, Zeolites 1 (1981) 161.

23. K. F. M. G. J. Scholle, W.S. Veeman, P.Frenken, G. P. M. van der Velden, Appl. Catal. 17 (1985) 233.

24. J. C. Jansen, F. J. van der Gaag, H. van Bekkum, zeolites 6 (1986) 225.

25. O.G. Somani, A. L. Choudhari, B. S. Rao, S. P. Mirajkar, Mater. Chem. Phys. 82 (2003) 538.

26. E. P. Parry, J. Catal. 2 (1964) 371.

27. T. M. Salama, I. Othman, M. Sirag, G.A. El-Shobaky, Micropor. Mesopor. Mater. 95 (2006) 213.

28. H.G. Karge, V. Dondur, J. Phys. Chem. 94 (1990) 765.

29. O. G. Somani, A. L. Choudhari, B. S. Rao, S. P. Mirajkar, Mater. Chem. Phys. 82 (2003) 538. 